\title{
THE INFLUENCE OF THE RAMMED STONE COLUMN FORMATION ON STRENGTH PARAMETERS OF THE SURROUNDING SOIL
}

\author{
Slawomir Kwiecień ${ }^{1}$, Piotr Kanty ${ }^{2}$, Jerzy Sękowski ${ }^{3}$ \\ ${ }^{1,2,3}$ Department of Geotechnics and Roads, Faculty of Civil Engineering, Silesian University of Technology \\ Riga, Latvia \\ E-mail:.'slawomir.kwiecien@polsl.pl; ${ }^{2}$ piotr.kanty@polsl.pl(corresponding author); ${ }^{3}$ jerzy.sekowski@polsl.pl
}

\begin{abstract}
This paper presents the results of field tests performed to examine the influence of the rammed stone column formation process on the surrounding soil. The influence is expressed by cohesion and internal friction angle changes. These parameters were determined in cone penetration test (CPTU) performed during and after the stone column formation process. The conducted tests have shown that the process of column formation affects the strength parameters of the surrounding soil. These changes are complex and come from a number of factors such as initial in situ soil characteristics, distance from the column and time. The field tests indicated a decrease in strength parameters during column formation process. Subsequently, when soil structure is rebuilt and consolidation process takes place, the strength parameters increase.
\end{abstract}

Keywords: dynamic replacement, stone columns, CPTU tests, in situ testing, ground improvement, field tests

\section{Introduction}

Building structures on soil of low bearing capacity or/and high compressibility requires deep foundations or ground improvement. The latter includes dynamic replacement method which is widely used in Poland (Gryczmański, 2003). Stone columns are formed in weak soils by means of tampering energy and backfilling with broken stone. The origins of the method lie in dynamic consolidation introduced by L. Menard (1972).

Accurate and comprehensive design approach has not been developed yet. The existing analytical solutions do not describe dynamic replacement in a correct way. In this design approach columns are approximated with cylindrical shape and strength parameters of surrounding soil remain as they were before dynamic replacement took place (Brauns, 1978; Priebe, 1976).

Previous research has indicated that column shape can be other than cylindrical (Kwiecień, Sękowski, 2012; Sękowski, Kwiecien, 2012) and that the parameters of the surrounding soil change (Kwiecień, 2009). These factors, when not included in the analysis, might lead to incorrect bearing capacity and settlement calculation using analytical or numerical (e.g. FE) methods.

Studies on column shape have been performed by the authors for several years. These have led to conclusions about the influence of ground and groundwater conditions on the shape of the formed columns (Kwiecien, Sękowski, 2012).

Previously, the authors conducted initial research on the influence of the formed columns on the changes in the surrounding soil. This did not provide comprehensive results (Kwiecień, 2009). Other studies (Stinnette et al, 1997) also did not give comprehensive solution as they were focused on the columns formed from sand rather than coarse material, which is preferable in Poland. Therefore, the authors decided to perform field tests focused on describing the influence of a single column formation on the strength and stiffness parameters of the surrounding soil. The influence was described by changes in the mentioned parameters measured in CPTU and DMT tests. The measurements from different distances from the column were taken during the column formation and after the column was completed. Due to wide scope of the original research the following paper focuses strictly on the results of strength parameters obtained from CPTU tests.

\section{Field tests}

\section{Field description}

Field tests were conducted in the south-east part of Poland in close proximity to a constructed main road.

The site was chosen on the basis of soil and groundwater conditions found in CPT tests conducted as part of ground investigation for the road project.

Firstly, square area $14 \mathrm{~m} \times 14 \mathrm{~m}$ was prepared. Secondly, the site was investigated by CPTU and DMT tests and boreholes in order to confirm the initial ground characteristics. The tests reached depths from $6 \mathrm{mbgl}$ (CPTU) to $7.5 \mathrm{mbgl}$ (borehole logs).

Previous studies indicated (Tschuschke, Kroll, 2012) that the ground on the site comprises four different layers of soils (Fig.1):

- medium dense silty sand and soft to firm sandy silt (up to a depth of $1.5 \mathrm{mbgl}$ )

- very soft to soft silt (between $1.5 \mathrm{mbgl}$ to $2.5 \mathrm{mbgl}$ )

- soft silt and loose/medium dense sand (up to $4.8 \mathrm{mbgl})$

- medium dense fine silty sand

The groundwater strike was found at $5.3 \mathrm{mbgl}$ and rose to $3.0 \mathrm{mbgl}$.

In terms of geological origins, all of the described layers are quaternary alluviums. 


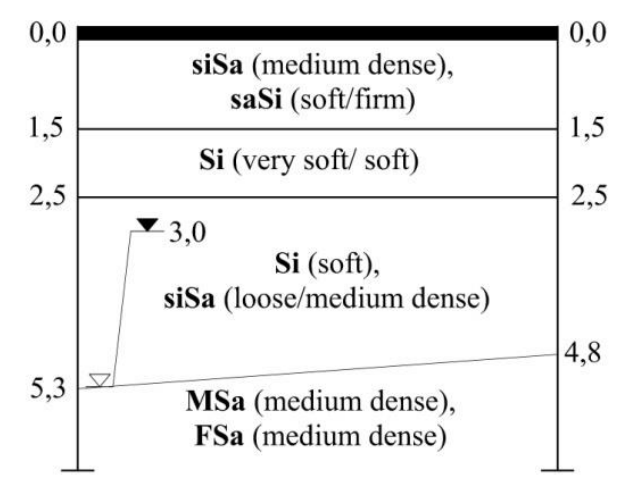

Fig. 1. Soil profile on the site.

\section{Methodology}

The presented results are part of the more comprehensive studies. The studies were focused on describing the influence of a single column formation on the strength and stiffness parameters of the surrounding soil. CPTU, DMT and inclinometer measurements were taken at different times and distances from the column.

First CPTU tests (series "a") gave results concerning the initial soil state before the column formation. Series "a" comprised five single tests, each of them in different location, i.e. one in the axis of the column and the rest at 2, 3, 4 and $6 \mathrm{~m}$ from the axis of the column.

The subsequent series consisted of four tests situated 2 , 3,4 , and $6 \mathrm{~m}$ from the axis of the column. The new series of tests was always slightly rotated around the axis of the column in order to avoid the influence of the previous CPTU penetrations.

The total number of series was seven (from "a" to "g"). The consecutive series were taken after: field preparation, $1 / 3$ of the column had been formed, $2 / 3$ of the column, the whole column had been formed, and 1, 8, 30 days after the column formation.

\section{Column formation}

The stone column was created by means of heavy barrel - shaped tamper (12 tonnes) falling from height of up to $15 \mathrm{~m}$ (Fig.2).

The formation process was divided into three stages, i.e. when the column height reached approximately $1 / 3$, $2 / 3$ and $3 / 3$ of the full height. After each of the stages had been completed, a series of CPTU tests was conducted.

A mixture of gravelly sand and broken stone (particle size $0-200 \mathrm{~mm}$ ) with ratio $1: 1$ was used as a backfill material.

Firstly, a crater was created during the column formation sequence due to the action of heavy load. The crater was next backfilled so as a new step starting with heavy load application could be initiated. The formation of $1 / 3$ of the column required six full steps in which tamper was dropped from 5-15 m height.

The second stage required drops from the maximum height of $15 \mathrm{~m}$. The created crater required to be backfilled four times.
The last stage consisted of five steps with decreasing dropping heights, i.e. the first one was from the maximum height of $15 \mathrm{~m}$, the last one from $2 \mathrm{~m}$.

The total volume of the backfilled material used to form the column reached $20.9 \mathrm{~m}^{3}$.

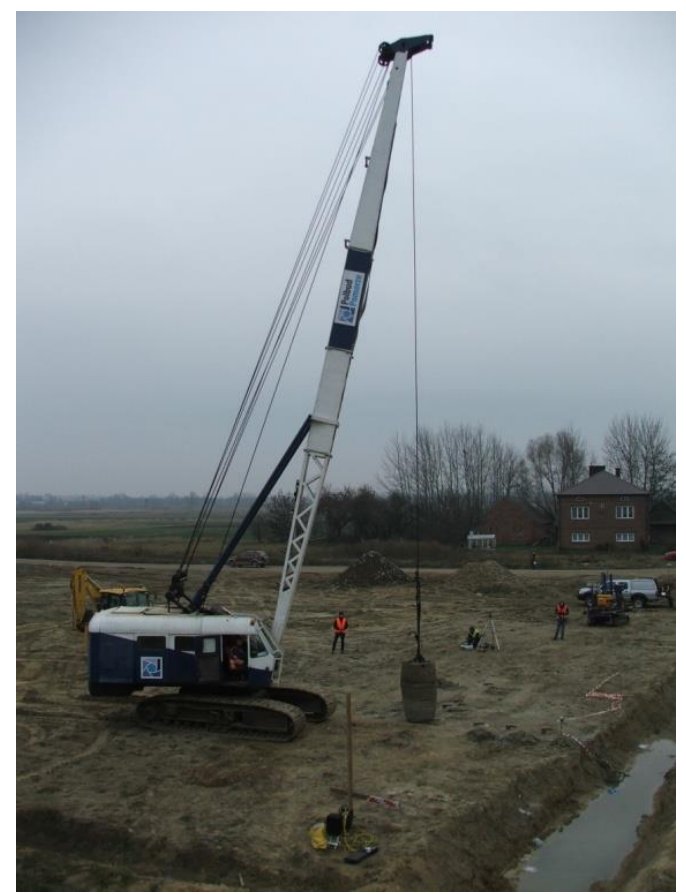

Fig. 2. Process of the stone column formation.

After CPTU testing had been finished, visual inspection (column excavation) was performed. This indicated that the shape of the column was similar to a barrel of changing diameter with increasing depth. The diameter at the top was around $1.9 \mathrm{~m}$, at the depth of $1.9 \mathrm{~m}$ it reached the maximum of $2.8 \mathrm{~m}$, finally, at the depth of $2.9 \mathrm{~m}$ the diameter was $2.65 \mathrm{~m}$. The depth of the column (i.e. its length) reached $3.8 \mathrm{mbgl}$. The column did not penetrate the strong layer of sands. The visual inspection revealed also the asymmetric shape of the column (Fig. 3 and 4).

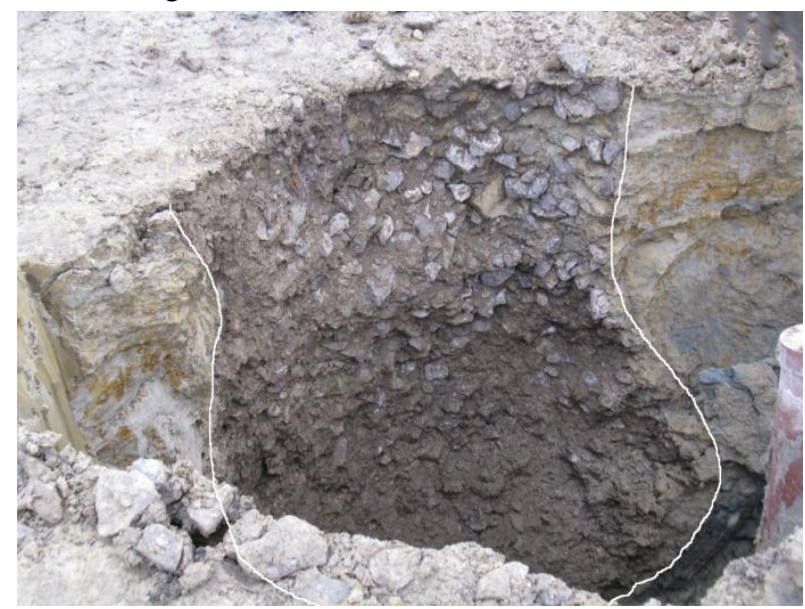

Fig. 3. Visual inspection (excavation) of the column. 


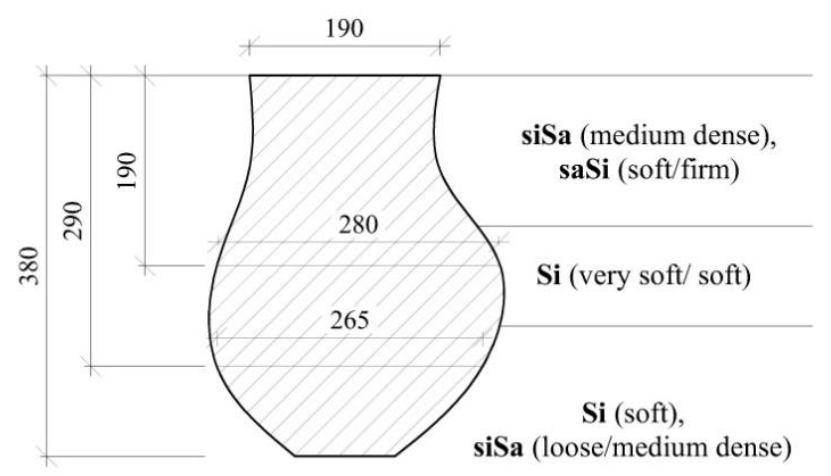

MSa (medium dense), FSa (medium dense)

Fig. 4. Detailed results of the visual inspection.

\section{CPTU tests (Tschuschke \& Kroll, 2012)}

CPTU tests were performed with a cone having crosssectional area of $10 \mathrm{~cm}^{2}$ and $60^{\circ}$ apex angle pushed into ground with $2 \mathrm{~cm} / \mathrm{s}$ speed. The area of cone rod was $150 \mathrm{~cm}^{2}$ and the piezometer was located just over the tip of the cone.

All of the CPTU tests were terminated at the depth of $6.0 \mathrm{mbgl}$. The testing field, CPTU track and measurement points are presented in Fig. 5.

Cone resistance $\mathrm{q}_{\mathrm{c}}$, sleeve friction $\mathrm{f}_{\mathrm{s}}$ and pore water pressure $\mathrm{u}_{2}$ were electronically recorded during the conducted tests. The obtained numbers were standardized to provide the following: corrected cone resistance $q_{f}$, friction angle $\mathrm{R}_{\mathrm{f}}$, pore pressure ratio $\mathrm{B}_{\mathrm{q}}$ and normalized cone resistance $\mathrm{Q}_{\mathrm{t}}$.

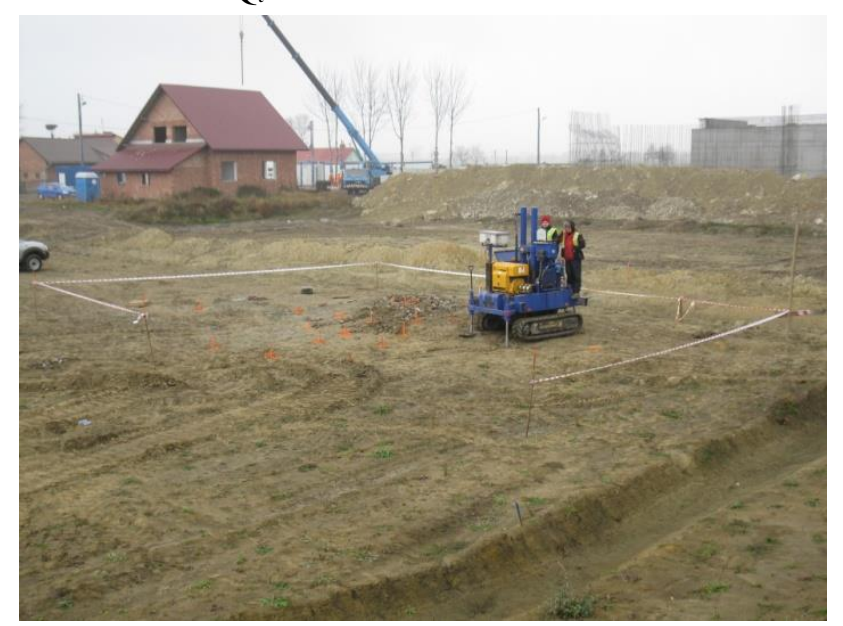

Fig. 5. CPTU testing in the field.
Soil types were determined in two stages. The first one was based on the procedure developed by Harder \& Bloh (Harder \& Bloh, 1988; Tschuschke et al.,1993). This allowed putting the layers into the classification system proposed by Poznan University of Life Sciences. The second stage consisted of layer separation according to procedure proposed by Hegazy \& Mayne (2002), and soil type identification based on graphs developed by Robertson (1990). The second stage allowed for verification with the previous one.

Soil in situ state for granular and fine-grained soils was described on the basis of diagrams developed by Poznan University of Life Sciences (Tschuschke, 1993; Tschuschke \& Wierzbicki, 1998) and other procedures (Jamiolkowski et al., 2001; Mayne). The ground strength parameters were defined on the basis of the following procedures: Senneset \& Janbu (1985), Lunne \& Robertson, (1997) and Mayne (2001).

\section{Results and discussion}

Measurements taken from CPTU tests allowed determining soil strength parameters before the column was formed (series 'a'), during the process of column formation (series 'b', 'c', 'd'), and finally after the column was completed (series 'e', 'f', 'g').

The presented results are focused on soil layers of the lowest bearing capacity and stiffness, i.e. two layers between 1.5 to $4.8 \mathrm{mbgl}$. The superficial layer has been excluded from the observation due to disturbing influence of working vehicles on the top of the surface. Additionally, the results in the top part would also be affected by changing moisture content due to weather conditions.

Fig. 6 and 7 present results for effective friction angle and cohesion for the chosen layers in measurement points located $2 \mathrm{~m}$ from the axis of the column. 


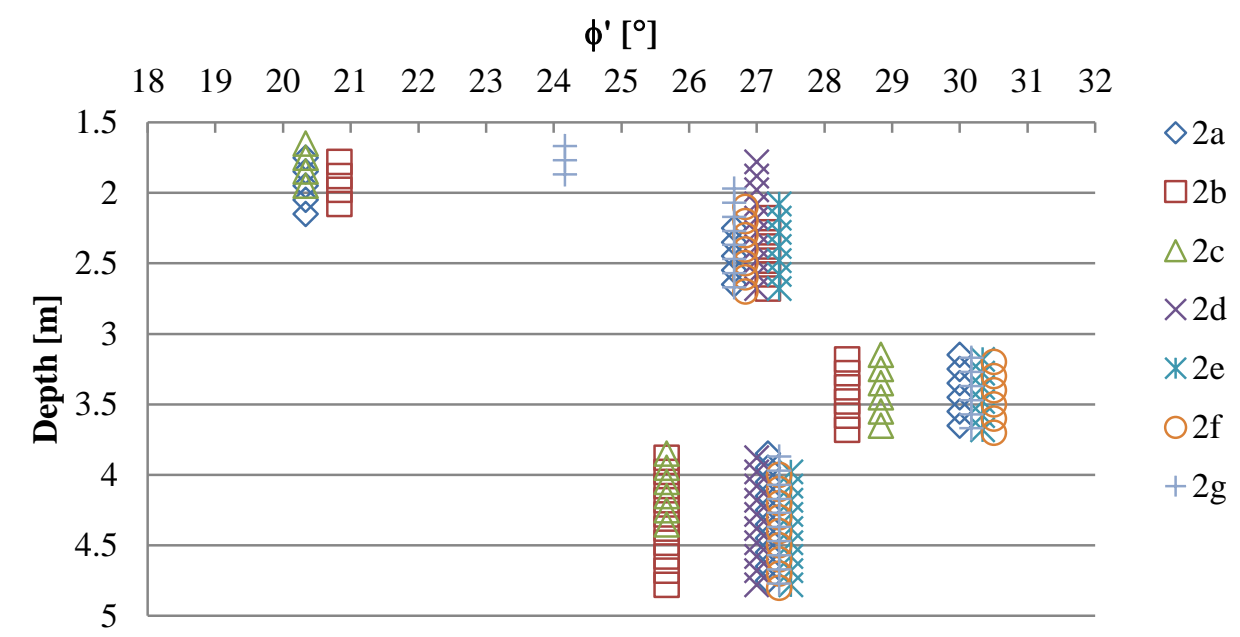

Fig. 6. Effective friction angle vs depth measured at point No 2, results from testing series a-g.

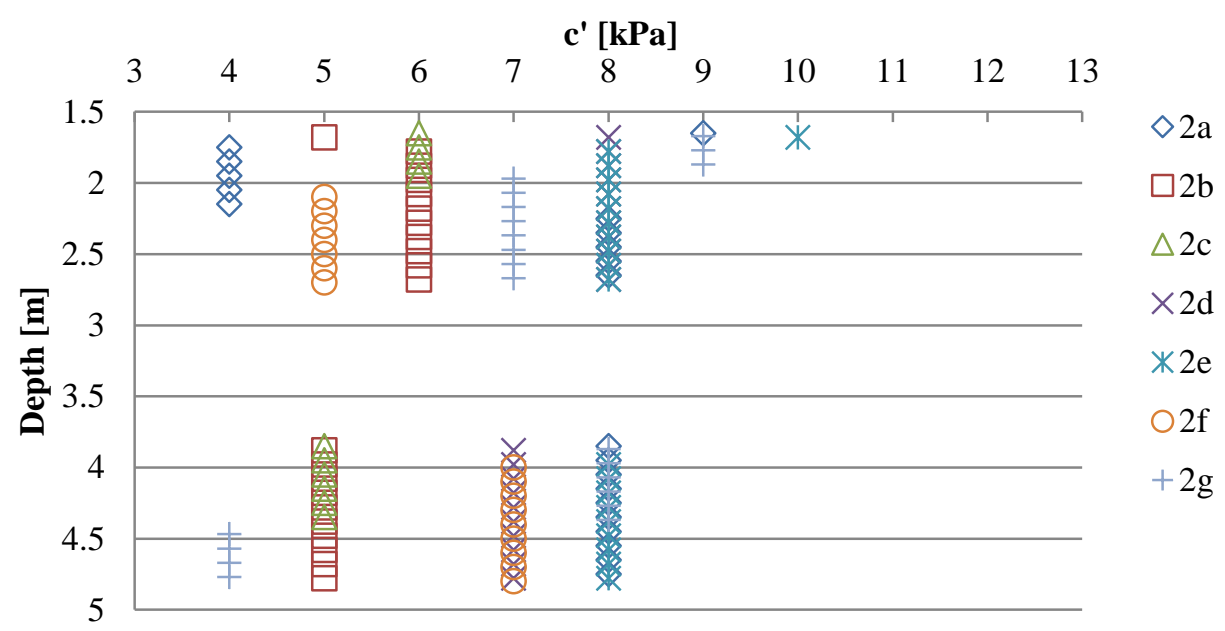

Fig. 7. Effective cohesion vs depth measured at point No 2, results from testing series a-g.

When analyzing the results it can be noticed that both effective friction angle and cohesion have changed. The character of these changes differs for both parameters.

The effective friction angle starts to increase during the column formation (layer from 1.5-3.0 mbgl) or just after the column formation is finished (layer below $3.0 \mathrm{mbgl}$ ). The final increase reaches few percent. On the contrary, effective cohesion generally (depths $2-5 \mathrm{mbgl}$ ) decreases during the column formation and starts to increase after the column is completed. Final values do not reach the values from the initial state. The same trend was found in previous studies conducted by the authors (Kwiecień, 2009) for ground in close proximity of a column.

Changes in values of effective frictional angle and cohesion for measurement point 3 (in the distance of $3 \mathrm{~m}$ from the axis of the column) are presented in Fig. 8 and 9.

The general trend for changes in strength parameters in measurement is similar to point 2 . The effective friction angle increases immediately at the depth of $2.0 \mathrm{mbgl}$. Below $2.0 \mathrm{mbgl}$ the values slightly decrease but finally reach higher level than the initial state (few percent). The effective cohesion rises over the initial values only up to depth of $2.0 \mathrm{mbgl}$. Similar results were obtained for the measurement point lying $4 \mathrm{~m}$ from the axis of the column (Fig. 10 and 11). Exceptionally, the friction angle at depth ranges 2.2-3.3 mbgl and 3.7-4.6 mbgl after a drop during the column formation time the values increased but did not reach the initial values.

The column formation process can also be noted in the measurement point situated $6 \mathrm{~m}$ from the axis of the column. Initially, a drop in friction angle and cohesion can be observed but with time both values increase and exceed the initial values (Fig. 12 and 13). 


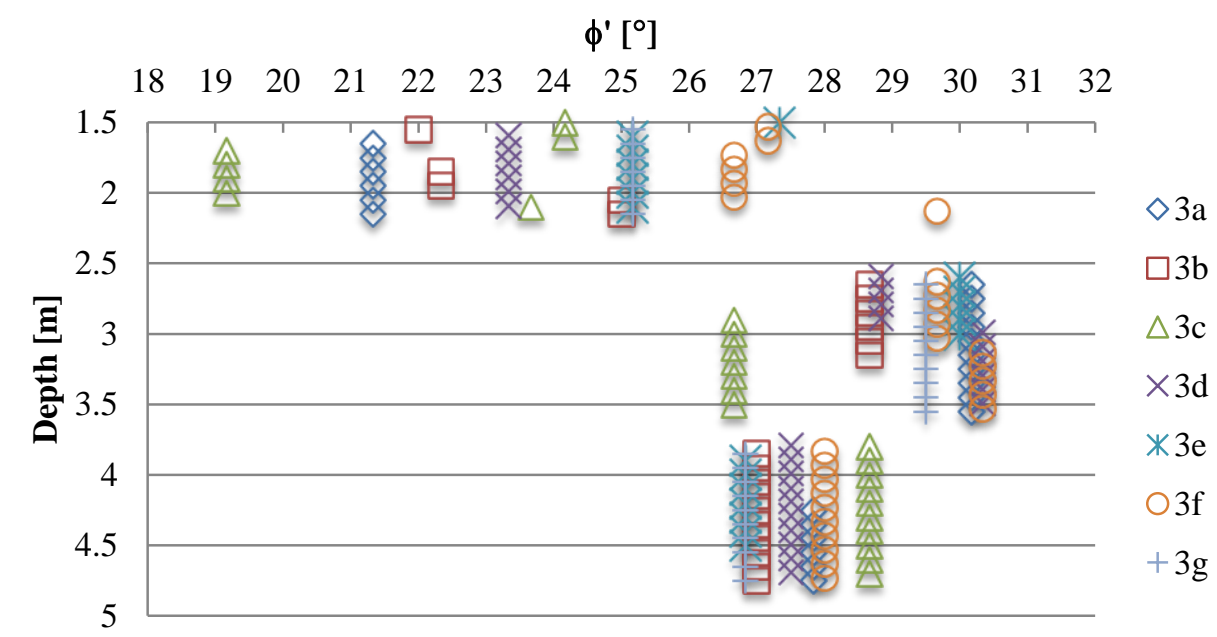

Fig. 8. Effective friction angle vs depth measured at point No 3, results from testing series a-g.

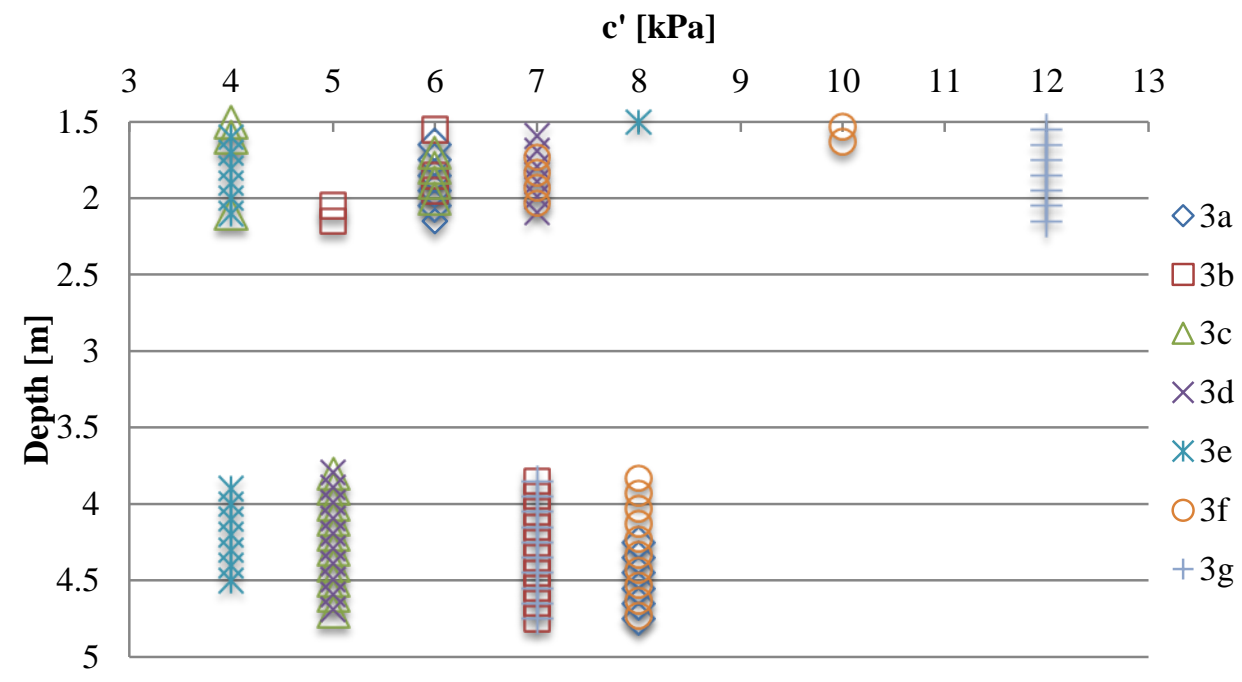

Fig. 9. Effective cohesion vs depth measured at point No 3, results from testing series a-g.

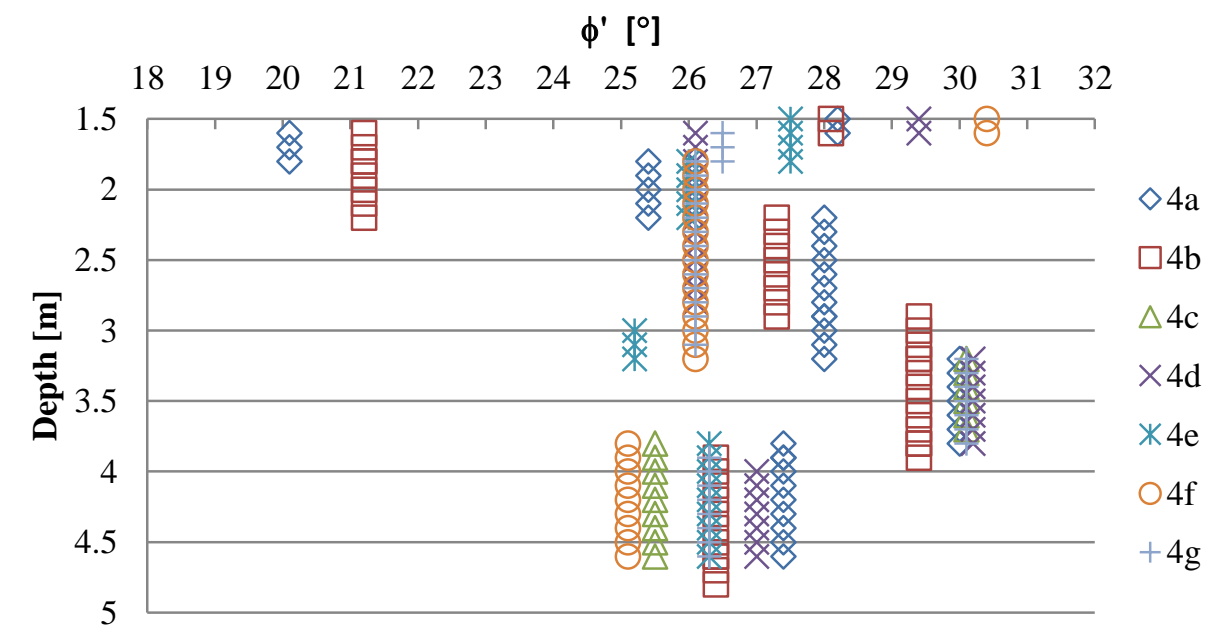

Fig. 10. Effective friction angle vs depth measured at point No 4, results from testing series a-g. 


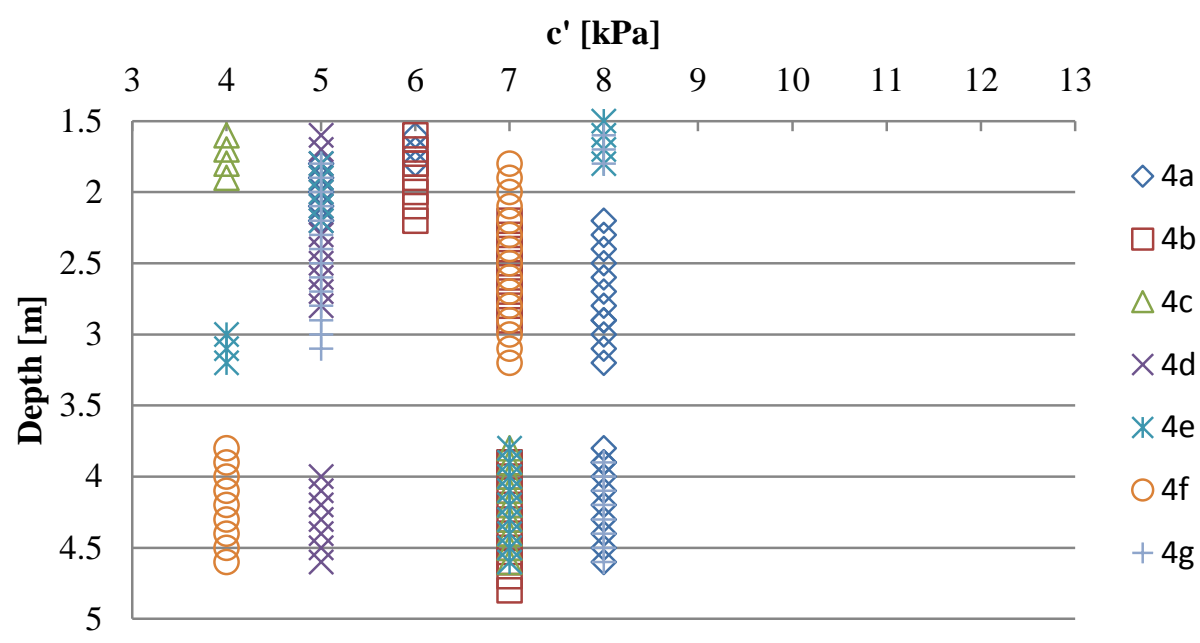

Fig. 11. Effective cohesion vs depth measured at point No 4, results from testing series a-g.

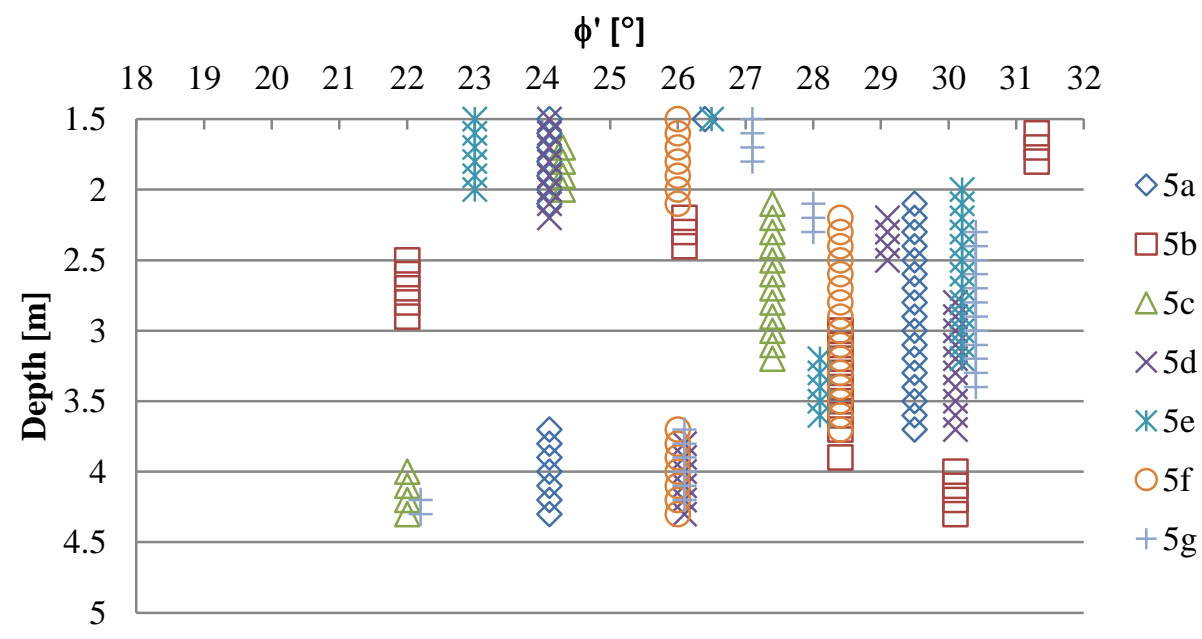

Fig. 12. Effective friction angle vs depth measured at point No 5, results from testing series a-g.

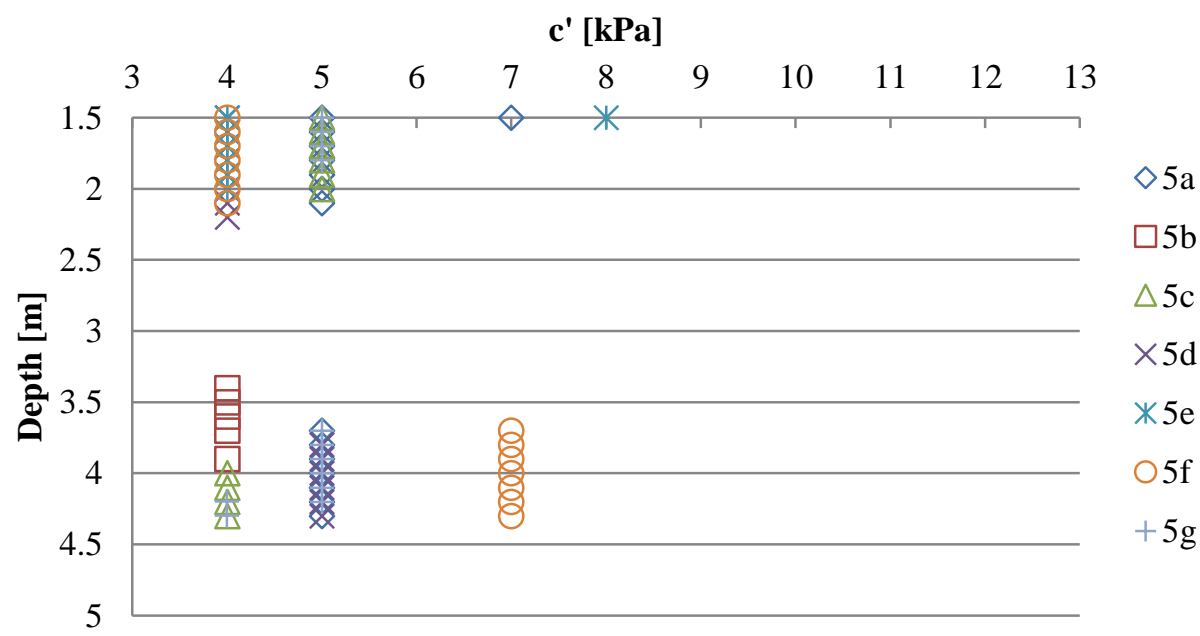

Fig. 13. Effective cohesion vs depth measured at point No 5, results from testing series a-g. 
When the results are analyzed it can be noticed that the column formation has caused changes in the strength parameters of the surrounding soil. These changes depend on the depth of the layer, its initial state and the distance from the axis of the column. By and large, all of the measurement points experienced decrease in strength parameters during the column formation process. This is caused by soil destructuralization due to the applied tampering energy and the increase of pore water pressure. After the formation process is finished, the soil structure is rebuilt and consolidation process takes place so the strength parameters increase. The increase for some layers exceeds the initial values. The greatest increase could be observed in the weakest layer (very soft to soft silt).

The field tests were terminated 30 days after the column completion, therefore further increase in the strength parameters is likely to occur.

The presented results are in agreement with the conclusions on the influence of dynamic consolidation on fine-grained soils (Menard \& Broise, 1975). Menard $\&$ Broise claim that the increase in bearing capacity depends on silt content and the type of chosen tampering energy.

\section{Conclusions}

The research has shown the results of the field test conducted in order to describe the influence of rammed column formation on the strength parameters in the surrounding soil. It is emphasized that the presented study was focused on a single column only. It is anticipated that for a group of columns, the consolidation process occurs faster, therefore the results would change.

The conducted testing proved that the column formation process leads to changes in the strength parameters of the surrounding soil. These changes are complex and result from a number of factors such as initial in situ soil characteristics, distance from the column and time. Field test measurements were taken up to 30 days after the column completion, therefore further increase in the strength parameters of the adjacent soil was possible. Further studies should be planned to inspect the surrounding soil behaviour for a longer period of time until no changes are recorded.

Further studies will be also looking into the respective changes of the surrounding soil stiffness as these also occur when columns are formed.

\section{References}

Brauns, J., 1978. Initial bearing capacity of stone column and sand piles. W. Proc. Symp. Soil Reinforcing and Stabilizing Techniques in Engineering Practise, Sydney.

Gryczmański, M., 2003. Wzmacnianie podłoża wbijanymi kolumnami kamiennymi. Przegląd doświadczeń śląskich. (Soil strengthening with the use of dynamic replacement method. The review of Silesian experience.) Inżynieria i Budownictwo, 3, pp.123-126. (In Polish).

Harder, H., Von Bloh, G., 1988. Determination of representative CPT-parameters. Proc. of the Conference the Penetration Testing in U.K., Birmingham.
Hegazy, Y.A., Mayne, P. W., 2002. Objective site characterization using clustering of piezocone data. Journal of Geotechnical and Geoenvironmental Engineering, 128 (12). http://dx.doi.org/10.1061/(ASCE)1090-0241(2002)128:12(986)

Jamiołkowski, M. et al., 2001. Evaluation of relative density and shear strength of sands from CPT and DMT. Symposium, M.I.T. Cambridge Mass.

Kwiecień, S.; Sękowski, J., 2012. Kolumny kamienne formowane w technologii wymiany dynamicznej. (Stone columns formed with the use of dynamic replacement technology). Monograph. Wydawnictwo Politechniki Śląskiej, Gliwice (In Polish).

Kwiecień, S., 2009. Próbne obciążenia wbijanych kolumn kamiennych i wpływ ich formowania na słabe otoczenie gruntowe. (Trial loading tests on driven stone columns and the influence of column formation process on low strength ground) W Monografii Problemy geotechniczne i środowiskowe $\mathrm{Z}$ uwzględnieniem podłoży ekspansywnych, Bydgoszcz, pp. 153-160. (In Polish)

Lunne, T.; Robertson, P. K., 1997. Cone Penetration Testing in Geotechnical Practice, Powell, Wyd. Blackie Academic and Professional, London.

Mayne, P. W., 2001. Stress-strain-strength-flow parameters from enhanced in-situ tests. Proc. of the International Conference on In-situ Measurements of Soil Properties and Case Histories, Bali.

Menard L., 1972. The dynamic consolidation of recently placed and compressible soils. Application to maritime works, Travaux, 1972, p. 452.

Menard, L.; Broise, Y., 1975. Theoretical and practical aspects of dynamic consolidation. Géotechnique, 25, 1, pp. 3-18. http://dx.doi.org/10.1680/geot.1975.25.1.3

Robertson, P. K., 1990. Soil classification using the cone penetration test. Canadian Geotechnical Journal, 27.

Senneset, K.; Janbu, N., 1985. Shear strength parameters obtained from static cone penetration test. ASTM Special Technical Publication, 883, San Diego.

Sękowski, J.; Kwiecień, S., 2012. Badania polowe kształtu kolumn formowanych metodą wymiany dynamicznej. (Field tests on column shape in dynamic replacement method). Inżynieria Morska i Geotechnika, 4/2012, pp. 426-432. (In Polish)

Stinnette, P. et al., 1997. A quality control programme for performance evaluation of dynamic replacement of organic soil deposits. Geotechnical and Geological Engineering, 15, pp. 283-302.

http://dx.doi.org/10.1007/BF00880710

Priebe, H., 1976. Abschatzung des Setzungsverhaltes eines durch Stopfveriichtung verbesserten Baugrundes. Die Bautechnik,. 53 (5), pp. 160-162.

Tschuschke, W.; Kroll, M., 2012. Interpretacja wyników testów dylatometrycznych (DMT) i statyczne sondowania (CPTU) na potrzeby Grantu badawczego pt. Analiza teoretyczna i doświadczalna wpływu wymiany dynamicznej na otoczenie gruntowe. (The interpretation of dilatometer tests (DMT) and cone penetration tests (CPTU) conducted for the research grant entitled "Theoretical and experimental analysis of the influence of dynamic replacement method on the surrounding soil") Poznań, In Polish).

Tschuschke, W. et al., 1993. Assessment of subsoil variability with the cone penetration test. Proc. of the $7^{\text {th }}$ International Conference on Application of Statistics and Probability, 2, Canberra.

Tschuschke, W., 1993. Zastosowanie metody statycznego sondowania do oceny stanu zagęszczenia budowli ziemnych. 
(Assessment of soil compaction within earth structures based on cone penetration test). Roczniki Akademii Rolniczej w Poznaniu, z. CCXLIV. (In Polish)

Tschuschke, W.; Wierzbicki, J., 1998. Zastosowanie techniki statycznego sondowania do oceny parametrów geotechnicznych podłoża. (Ground parameter determination on the basis of cone penetration test) Współczesne Problemy Geologii Inżynierskiej w Polsce, Instytut Geologiczny UAM w Poznaniu.(In Polish)

\section{Acknowledgements}

This outcome has been achieved with the financial support of the National Research Center within project No. 1989/B/T02/2011/40. 